\title{
"An Authentic Record of My Race": Exploring the Popular Narratives of African American Religion in the Music of Duke Ellington
}

\author{
Vaughn Booker
}

Thru all the bloody, burdened years

Boola has clung to the Word of God.

Boola believed.

His faith remained the Kindly Light

To lead him safely through the darkness

Of despair, misery, hunger, pain.

God was good, but in His infinite wisdom

Would allow one blessing at a time.

And he answered honest prayers.

He opened Boola's mouth

And made those Golden sounds come out.

He touched Boola's heart

And gave those golden sounds a lilt...

A depth ... that no one else could duplicate.

He nudged the whites

And said to them: "LISTEN!"

They listened and were lifted up

Those golden tones were lulling tones.

Their consciences were glad. Glad the slaves

Had found the Bible... Singing to their God ...

Reassuring, too, it was. Calming. Healing.

Harsh words abandoned. A happy medium!

The spiritual was soothing to singer

And slavemaster, too!

-Duke Ellington ${ }^{1}$

\section{Introduction}

Jazz pianist, composer, and arranger Edward Kennedy "Duke" Ellington (1899-1974) will always be most famous for his shorter, popular compositions such as "It Don't Mean a Thing (If It

Religion and American Culture: A Journal of Interpretation, Vol. 25, Issue 1, pp. 1-36, ISSN: 1052-1151, electronic ISSN: 1533-8568. (C) 2015 by The Center for the Study of Religion and American Culture. All rights reserved. Please direct all requests for permission to photocopy or reproduce article content through the University of California Press website at http://www. ucpressjournals.com/reprintinfo.asp. DOI: 10.1525/rac.2015.25.1.1. 
Ain't Got That Swing)," "Sophisticated Lady," "Caravan," "Satin Doll," and "Take the 'A' Train." ${ }^{2}$ In a career spanning more than six decades until his death in 1974, the big band leader wrote thousands of compositions to capture the American public's imagination and ears while jazz as a genre underwent various shifts and as audiences moved from dancing in clubs to enjoying the music as a more stationary, intellectual exercise. These songs reflected Ellington's various romances-with places, people, and popular stories, both fictional and historical —and he often added to their musical content specific titles to represent the experiences and concepts in American life that he considered significant.

Duke Ellington was also in a romantic relationship with African American history, and he conceived of his profession as a musician as an opportunity to voice-at times subtly, other times overtly and dramatically - a love for African American people, be they black, brown, or beige. Ellington celebrated the narratives of a vast black history, stretching from the ancient Middle East and North Africa, through Judeo-Christian scriptures, and culminating in the twentieth-century experience of African Americans as they continued to move "up from slavery" and resist Jim Crow segregation. By all accounts, even his own, Ellington was also a deeply religious man who made explicit his understanding that a musical career was also a divine calling. Between 1965 and 1973, Ellington composed three "Sacred Concerts" to capture the deep religious reverence that he tied to his personal history, reflections on race, and the people and new theological ideas he encountered as an elder musician.

The purpose of this article is not to narrate Ellington as a religious musician in an ostensibly secular musical genre-jazzthrough the example of his "Sacred Concerts," for various works have done justice to the late-career Ellington's music in this regard. ${ }^{3} \mathrm{I}$ am more concerned with Ellington as one of the world's most prominent African American musicians during the first half of the twentieth century and his ability to construct a musical portrait of African American existence largely on his own terms. I am most concerned with Ellington's ability to reflect, capture, and propagate popular narratives of African American religiosity. This article explores the modes and methods Ellington employed to signify musically the supposed "nature" of African American religion, examining how his sounds became the backdrop to Harlem Renaissance portraits of a Negro "folk," late-nineteenth and early-twentieth-century concepts of African American history, and sociological (and political) definitions of African American religion. Duke Ellington's popular musical corpus allows for an understanding of the intellectual work a musician 
performs when afforded the professional liberty to tell stories through song. Listening is an intellectual exercise, whether the music heard is accompanied by dance or not, and it is fruitful to discern the complex relationships between the composer, the music, the audience, and the (un)intended message.

In the first section, I establish Duke Ellington the musician as a member of the "New Negro" intellectuals in the Harlem Renaissance, an elite (male) group of African Americans in the 1920s and 1930s New York scene who were committed to constructing a public portrait of an African American "folk" culture. In the second section, I examine how Ellington's concept of African American history led him to rely, in his work, on well-established popular conceptions of African American religion to propagate a cultural approach for black social progress. After exploring several Ellington compositions that express common racial narratives of biblical history-wherein African Americans read key scriptural figures as black and argued Africa's consequential presence-I examine his rendering of the African American spiritual tradition in the 1929 short film Black and Tan and in his 1943 composition "Come Sunday" (including Mahalia Jackson's 1958 version) as his attempts to define, through music, these songs (and the religion they represent) as the "classical" cultural element of African American history. In the third section, I explore what I define as Ellington's "secular black sermons" in his recording of a popular 1931 tune "Is That Religion?" and in his 1963 stage show, My People, as an explicit rendering of the African American Christian preaching tradition for the purpose of celebrating his narrative of African American history. These pieces, composed and performed in an era when most Americans gradually became aware of African American civil rights demands and the problem of Jim Crow, captured the popular characters, rhythms, and sounds of the African American Christian sermons with which Ellington was familiar, but without including any expressly theological content.

In her study of the American film industry and its representations of African American Christian beliefs and practices in the early decades of the twentieth century, Judith Weisenfeld, historian of African American religions, writes, "The major Hollywood films of the period generally mobilized black religious aesthetics in service of an essentialized understanding of African American religion, presenting something the filmmakers understood to be the fundamental religious and racial nature of the "Negro race.'" Weisenfeld turns to examine the ways that African Americans presented "filmic interpretations of Christianity in African American contexts" in order to situate the technology of film as a constructor of "relationships between 
religion, race, and American identity." ${ }^{4}$ This essay seeks to extend Weisenfeld's concern about essentializing representations of African American religion (Christianity, in this instance) by focusing on a sympathetic African American cultural producer within the music profession. Duke Ellington composed modern music. He also maintained a romantic orientation toward African American history and the academic constructions of an African American folk during his lifetime. However, because popular conceptions of African Americans in the early twentieth century often rendered them a "primitive" folk (in the sense that they were culturally static or timeless), the unintended consequence of many of Ellington's works was the propagation of a perpetually "classical" African American religion and religiosity that were inherently pastoral, closely related to the primitive, never modern. Ellington's portrait of African American Christianity was never expressly "primitive." ${ }^{5}$ However, given the prevalent narratives of African American religion upon which the composer relied, Ellington's music was, simultaneously, an intentional project of racial uplift and an unintentionally complicated representation of a race and its presumed religiosity.

\section{Jazz and the Harlem Renaissance: Ellington's Renderings of an African American Folk}

With the exception of Langston Hughes, many black and white intellectuals in Harlem during the 1920s who desired the creation of a high culture of music for "a new Negro and his distinctive cultural expression," in the words of historian Nathan Huggins, disregarded many players in the world of jazz. ${ }^{6}$ For the African American writer Alain Locke, the spirituals, blues, and jazz were African American creations that would serve as the essential ingredients for American musicians "to build their classical music"; however, they could not serve as art forms of historical merit for a nation in their present shape. ${ }^{7}$ According to the literary historian George Hutchinson, African American print journal outlets such as Opportunity signified jazz with genuine cultural appeal to both the "masses" and the "artists." With jazz, African American musical artists were able to forge "the key to the interpretation of the American spirit." ${ }^{8}$ Nevertheless, for some African American writers such as Locke and James Weldon Johnson, an African American "genius" was necessary to elevate the entire jazz enterprise to something worthy of designation as a true American art form. Such a young artist in Harlem was not readily apparent, according to Huggins, since "the jazzmen were too 
busy creating a cultural renaissance to think about the implications of what they were doing." ${ }^{\prime \prime}$

Music scholar John Howland notes that a later, more reflective Alain Locke wrote The Negro and His Music in 1936 about jazz in a hierarchical categorization: "cheap low-browed jazz" was the mediocre, manufactured music for popular consumption; "worthwhile jazz" was the realm of instrumental virtuosos and jazz composers; and "classical jazz" was home to "a type of music that successfully transposes the elements of ... jazz idioms ... [to] more sophisticated ... musical forms." ${ }^{10}$ Such so-called classical jazz consisted of African American composers who could employ racial folk idioms in music while writing in "nonracial" classical forms. For Locke, Duke Ellington was the artistic exemplar of "worthwhile jazz" and the sole musician among the major jazz artists of the era who might achieve Locke's ideal, "classical jazz" form.

Ellington, an African American male pianist born in 1899 and raised in the black middle class of Washington, D.C., arrived in Harlem in 1923 formed by a family and class of African Americans who viewed racial uplift as a professional duty. According to the music historian Mark Tucker, the Ellington who matured as an artist in the 1930s fit perfectly Alain Locke's jazz archetype: "Ellington came to embody the ideals of the New Negro artist in his dignified manner and cultivated persona, his social consciousness, his use of vernacular sources as the basis for original compositions, and his deep pride in the Afro-American heritage. ${ }^{11}$ Contrary to Huggins's belief that jazz musicians engaged more in the production of music than in the reflection on its significance, Ellington made sure to articulate in his day the social importance of his music as a racial and cultural reality in addition to its emblematic representation of what it meant to be an American. Duke Ellington's consistent rhetorical appreciation of his music as essential "Negro folk music" also allowed him to present a jazz that existed as an important vehicle for a romanticized concept of African American religious history. He promoted a view of African American Protestantism that necessarily depicted a static portrait of a (racialized) religiosity that served the Harlem Renaissance project of addressing social inequality without recourse to political advocacy. It is first necessary to understand Ellington's concept of folk culture, and its resonance with other artists in the Harlem Renaissance era, in order to grasp its importance for his appreciation of religious practices and beliefs as "folk."

Nathan Huggins observed that many Harlem Renaissance elites were invested in articulating the heritage of African Americans, 
a heritage that must be viewed in light of the earlier civilizations of Africa but not seen necessarily as a pure extension of those cultural forms and practices. Renaissance women and men sought to compile a set of artistic (musical, ritual, and material) productions to serve as a representative African American "folk tradition" indicative of a particular historical experience in America. Huggins noted that, in the entertainment industry as well as in the world of spiritual matters, one may find the fruits of African American productive agency: "While the Negro had been denied by both whites and sophisticated blacks, he was unconsciously pouring out, in his own entertainment and for his own soul's needs, the raw folk materials upon which any American music or literature would have to rest.... Sophisticated Negroes began to find value in the peasant character of the mass of American Negroes." ${ }^{\prime 2}$ African Americans produced America's "only genuine folk tradition," and George Hutchinson added to this Renaissance narrative a protectionist impulse-to make sure the dominant society (with its penchant for exoticizing and primitivizing black peoples) would not conflate African American cultures and African cultures; a "particularized and historicized yet respectful revaluation of African cultures" was necessary. The African American "folk" must be viewed in a light that "resisted [black people's] enshrinement as exotic 'others,'" and those invested in constructing notions of folk culture must be attentive to the "historical experience in America as determinant of a specifically 'native' American/Negro cultural matrix." Hutchinson also noted that, for Alain Locke in particular, African American folk forms remained "primitive" (as opposed to "classical") because they had not yet "mastered [their] idiom of expression"; African American culture as an indigenous, "mixed" American culture remained "at a relatively early period of development" in comparison to the cultural traditions of other "civilizations." ${ }^{13}$

Ellington shared a similar disposition to the significance of his music and its dependence on African American folk traditions in this light. Writing his first article in the British magazine Rhythm in 1931, Ellington suggested as much to a non-American audience:

The music of my race is something more than the "American idiom." It is the result of our transplantation to American soil, and was our reaction in the plantation days to the tyranny we endured. What we could not say openly we expressed in music, and what we know as "jazz" is something more than just dance music. When we dance it is not a mere diversion or social accomplishment. It expresses our personality, and, right down in us, our souls react to the elemental but eternal 
rhythm, and the dance is timeless and unhampered by any lineal form. ${ }^{14}$

Ellington signified both dance as a practice with historical roots in a race's American experience and jazz as a specific, modern art form that appropriated dance in order to demonstrate its essential purpose of expressing a people's collective personality. In this rendering, jazz as American reflects a particular African American sentiment, perspective, and purpose, although the music and dance may also be enjoyed by nonblacks and non-Americans.

Before a scheduled appearance in Glasgow, Scotland, Ellington gave an interview to a local newspaper on the different perceptions of folk cultures in the music of different nations:

"Some people say that my music is uncouth and without form-a weird conglomeration of blatant discords which never has, and never will mean anything at all."

"But" - and here Duke Ellington, the negro [sic] composerconductor, looked at me with twinkling eyes-"What, may I ask you as a Scotsman, do the same people think about bagpipe music? It is quite as weird, quite as 'tuneless.' But it is recognized as the music of a nation, as folk music."

Thus Duke opened his argument.

"My contention about the music we play is that it also is folk music, the result of our transplantation to American soil, and the expression of a people's soul just as much as the wild skirling of bagpipes denotes a heroic race that has never known the yoke of foreign dictatorship."15

Ellington as a musical artist asserted his participation in a Renaissance culture of capturing the historical experience of an entire group of people, presenting a musical art form to stand on par with the music of other nations conceived, similarly, as representative of a people's essential existence and story. Ellington as a Renaissance artist was representative of the nationalistic impulse in arguing for a conception of African Americans as a nation with a distinctive national soundas he stated in one interview, Ellington was unable to truly "get" music that did not reflect or speak to folk experiences characteristic of African American existence. Responding to an English composer and music critic in 1935 who declared him an artist on par with German composer Johann Sebastian Bach, Russian composer Igor Stravinsky, and French composer Maurice Ravel, Ellington took care to elaborate a racially essentialist predisposition required to understand his music: 
Asked about his own ideas of music, Ellington said:

"A black man feels [a] black man's music most, and that's what I want to write. My aim is not only to make jazz. It is to make new, unadulterated music expressing the character and moods of the Negro. It's hard for me to get other kinds of music. Take Stravinsky, he has a terrific conception and he sure knows how to handle his material, but I really can't feel his music with my heart. I'm wild about some of it though. What's that bird ... 'Firebird'-that's it. Great stuff!"16

As evident in his desire "not only to make jazz," Ellington certainly played around with popular characterizations of his music, embodying an artistic elusiveness about what exactly he was up to as a music composer: "I am not playing jazz. I am trying to play the natural feelings of a people. I believe that music, popular music of the day, is the real reflector of the nation's feelings." Popular uses of the term "jazz" were likely not to capture its true meaning (for musicians) beyond the level of mass consumption of music, and Ellington saw this emerging category of African American music as evolving alongside-and according to-the ongoing shared experiences of African Americans: "Some of the music which has been written will always be beautiful and immortal. Beethoven, Wagner and Bach are geniuses; no one can rob their work of the merit that is due it, but these men have not portrayed the people who are about us today, and the interpretation of these people is our future music [emphasis added]."17

Ellington's jazz, whatever the present moment, reflected always the established corpus of African American folk culturethose elements of African American life already considered worthy of status as folk expressions and rendered in a fixed sense by singers, dancers, anthropologists, historians, and other performers and compilers of an African American national culture. ${ }^{18}$ While his commitment as a musician seemed to imply a progressive sensibility about music's instrumental, melodic, and improvisational possibilities, elements of African American folk culture such as black (in his specific case, Protestant) Christian practices registered for Ellington only insofar as they were constructive cultural memories - they had to be well established in his historical memory and in his perception of the prideful cultural production of African Americans throughout history. That which was new-in dance, song, and worship-would be incorporated and reflected on by a later Ellington (or, hopefully, by other musicians who followed his example) in any attempts to signify them as classical, for they were not yet established folk culture. 
In 1931, Ellington took pride in Harlem as a space to symbolize the African American attempt at "civilization" at the same time that he lamented the absence of a music to construct an African American folk culture to compare with similar production found in the literary world:

To-day [sic] we are an important and intrinsic part of the population of the great United States of America. In Harlem we have what is practically our own city; we have our own newspapers and social services, and although not segregated, we have almost achieved our own civilization. The history of my people is one of great achievements over fearful odds; it is a history of a people hindered, handicapped and often sorely oppressed, and what is being done by Countee Cullen and others in literature is overdue in our music. ${ }^{19}$

Ellington's goal was that, through music, "an authentic record of my race written by a member of it shall be placed on record" alongside the great works representative of other national cultures in the Western world, and his commitment to a folk understanding of African American existence led to an appreciative-but complicated-rendering of the form and possibilities of African American life. ${ }^{20}$

Cultural historian Eric Porter notes that, because most jazz musicians in history have been male, jazz discourse has generally been defined by men (black and white). He writes, "In order to understand the contours of the intellectual history of jazz, [we] must come to terms with the centrality of masculinity in the formulations and interpretations of jazz history." ${ }^{21}$ Ellington as a male jazz musician made it abundantly clear that he was comfortable with his public interpretations of African American history and culture, and it is necessary to understand how his specific renderings of history impact (and participate in) larger social narratives of African American religion. The next section explores Ellington's complex representation of spirituals, elements of African American folk culture for which the very act of their preservation in musical performances was always intertwined with their musical evolution at the hands of composers, arrangers, and performers.

\section{Folk Religious Representations: Spirituals in Ellington's Music}

\section{Religious Imaginings of Ancient Africa}

The Harlem Renaissance of the 1920s inaugurated a "cultural politics" that relied on the celebration and proliferation of popular African American artistic production. Cultural politics represented a novel, alternative strategy for racial progress in contrast to the 
established, Du Boisian sociological and political programs of national organizations (such as the National Association for the Advancement of Colored People), which often produced generalizations about areas of black culture, like religion, in the pursuit of substantive social policy changes. ${ }^{22}$ With their focus on culture, Renaissance artists, writers, and musicians were now able to signify traditions such as African American spirituals as Du Bois had in his famous 1903 work, The Souls of Black Folk. Eric Porter writes, "Du Bois' treatment of this form of music anticipated future debates by situating music at the nexus of race and nation, by emphasizing the realm of spirit as a site of black achievement, and by simultaneously theorizing black musical culture as a gift to American society and as a vehicle for African American liberation." ${ }^{23}$ Harlem Renaissance artists insisted on the essential signal of black artistic brilliance in all black cultural production. For these "New Negro" artists in the supposedly immoral, urban North, culture could be signified anew in the 1920s as the elements of a folk's historical resilience. Consequently, they conveyed to the wider society a "classical" portrait of African American religiosity. ${ }^{24}$

The practice of framing cultural elements such as the spirituals as classical was not unique to 1920s New York-artists such as Duke Ellington entered Harlem's musical scene with well-established narratives of African American history. Growing up in Washington, D.C.'s black middle class at the turn of the twentieth century, Ellington's mother took him to at least two churches every Sunday (Nineteenth Street Baptist and John Wesley A.M.E. Zion, his father's family church) ${ }^{25}$ Ellington was educated in an environment that saw the staging of historical plays and pageants by civic groups, schools, and churches. According to Mark Tucker, Washington, D.C., and other American cities saw pageants such as Du Bois's The Star of Ethiopia, which purported to cover " 10,000 years of the history of the Negro race and its work and suffering and triumphs in the world." Pageants such as The Star of Ethiopia began with a conception of black world history inaugurated by a classical, African period, containing the histories of Egypt and Ethiopia, and extended to African American life at the start of the twentieth century. Other pageants such as The Evolution of the Negro in Picture, Song, and Story similarly encouraged musical and visual dramas that captured a history of an African American slavery that produced "sorrow songs" (a form of spirituals that transition from somber themes of despair to themes of hope and joy), outlined Emancipation and the socioeconomic promises of Reconstruction, and concluded with the present "Day of Opportunity." ${ }^{26}$ In his memoir, Ellington's reflections on his early education in 
African American history reveal an early-twentieth-century culture of instilling racial pride through programs crafting artistic, historical narratives of African American social progress:

When we went out into the world, we would have the grave
responsibility of being practically always on stage, for every
time people saw a Negro they would go into a reappraisal of
the race.... As representatives of the Negro race we were to
command respect for our people. This being an all-colored
school, Negro history was crammed into the curriculum, so
that we would know our people all the way back. ${ }^{27}$

Ellington came from and participated in a culture that signified African countries such as Egypt and Ethiopia as ancient examples of mighty and formidable black civilizations, a people who traced the racial lineage of African-descended peoples throughout the Hebrew Bible. In 1958, Ellington had the opportunity to meet with Queen Elizabeth II and offered to compose "a real royal suite" for her. The Queen's Suite (1959), by Ellington and his co-composer and arranger Billy Strayhorn, consisted of six movements, one of which bore the title "Apes and Peacocks." The title comes from a verse in the Hebrew Bible, 1 Kings 10:22b ("Once every three years the fleet of ships of Tarshish used to come bringing gold, silver, ivory, apes, and peacocks."), and Ellington wrote that this song "was inspired by reading the Bible about the Queen of Sheba and all the gifts she brought to King Solomon." When the English jazz historian Stanley Dance asked Ellington the significance of this title, Ellington instructed him to "reread the Old and New Testaments." 28 Ellington participated in an African American history of signifying many biblical characters such as the Queen of Sheba as Ethiopian and the Hebrew King Solomon as the presumed descendant of dark-skinned Ethiopians, ${ }^{29}$ and the present Ethiopian monarchy attests to this belief in their claim that Solomon and the Queen of Sheba produced a son together who founded the ancient Ethiopian empire. One earlier Ellington composition, titled "Menelik, the Lion of Judah" (1941), revealed the composer's celebration of Menelik II, the late-nineteenth-century Ethiopian emperor believed to be one such descendant of King Solomon and the Queen of Sheba. Ellington later reiterated the concept of Solomon's blackness in his final composition, The Three Black Kings (Les Trois Rois Noirs) (1974), completed by his son, jazz trumpeter Mercer Ellington, for jazz band and symphony orchestra and scored for the Alvin Ailey American Dance Theater by Luther Henderson, Jr. ${ }^{30}$ The suite's three movements are named for different black royalty: "King Balthazar" (a name for one of the biblical Magi/Wise Men who 
visited the infant Jesus and who is considered black), "King Solomon," and "Martin Luther King, Jr." The ability to select biblical characters, titles, and themes for his jazz compositions represents one of Ellington's practices for advertising-overtly or with subtlety-his desire to create music that was both beautiful and racially inspiring.

\section{Black and Tan}

Don George, a lyricist for Ellington in the 1940s, wrote that Ellington "musicalized" African American history. The first two decades of his career saw conscious attempts to assert an appreciation for blackness in songs such as "Black and Tan Fantasy" (1927), "Symphony in Black" (1934), "Black Butterfly" (1936), "Black Beauty" (1938), and in Black, Brown, and Beige (1943), Ellington's extended symphonic "tone parallel to the history of the Negro in America." George recalled how Ellington often shared with him notable African American milestones:

Duke was tremendously well versed in black history. He told me about the invasion of Africa by Portugal, shortly after Columbus discovered the New World, when the Portuguese set up the slave system as we knew it. He told me about Crispus Attucks, a black [sic] who was the first casualty of the Boston Massacre; about the underground railroad that smuggled slaves to the North during the Civil War; about Harriet Beecher Stowe. He made me aware of Marcus Garvey and George Washington Carver. ${ }^{31}$

These historical narratives, which Ellington carried throughout his life, relied on an expansive conception of an African American classical past, and black music existed most immediately for members of the black middle class such as Ellington and other "New Negroes" to mold into a proper, classical form to present to a wider, predominantly white audience. One such early presentation was the 1929 short film Black and Tan, starring Ellington as himself and the African American actress Fredi Washington as a dancer and Ellington's girlfriend. The tragic story highlighted the reality of black cultural limitations-despite black artistic creativity-due to America's de facto and de jure racist practices. Both Ellington and Washington represent respectable black artists who must struggle to make ends meet despite the quality of their artistic production, and Black and Tan featured one of Hollywood's first portraits of professional African Americans to counter widespread film images of black lasciviousness or violent propensities. ${ }^{32}$ In this short film, Washington, advised by her doctor to quit dancing because of her ill health, ends up collapsing on 
stage after an exuberant performance to "Cotton Club Stomp," played by Ellington and his orchestra. What follows is a scene with Washington on her deathbed and Ellington at her bedside, featuring the shadows and music of Ellington musicians and a choir. As the scene opens, this choir can be heard singing the spiritual "Same Train" ("Same train [2x], carried my mother, same train [3x], carried my mother, same train'll be there tomorrow, same train"), a sign of Washington's impending death. ${ }^{33}$ According to James Weldon Johnson in his two-volume The Books of American Negro Spirituals, "Same Train" represented African Americans' "sensitiveness and quick response to the whole gamut of human emotions" coupled with an innate ability to innovate classical images and metaphors for death:

The age-old symbol of death's convoy is a boat crossing a stream or a ship leaving one port and entering another. The Negro has made frequent use in the Spirituals of this classic symbol; but turn to the song, Same Train, and you will see that he does not hesitate to scrap the stereotype and create a new symbol out of his own everyday experiences. He dares to do this, and, what is more important, he does it to the point of perfection. The imagery is not lessened and see how the inevitability of death is insistently suggested in the inevitably recurring "Same train. Same train."

Spirituals such as "Same Train" represented, for Johnson and others, an inherent African American genius for speaking to universal existential themes. Johnson argued that "the Negro was using as his medium the infinitely varied rhythmic patterns of his native African music, to which he has added a new-found harmonic strength and melodic beauty," ${ }^{\prime 35}$ and Johnson captured a narrative in which presentday spirituals existed as the evidence of a folk's modern refinement of a classical African past and musical inheritance. As performed in Black and Tan, "Same Train" featured vocal harmonies indicative of a concert arrangement of a spiritual. According to Judith Weisenfeld, such arrangements drew on popular American and European classical musical themes, and their dramatic performance on stage and screen represented transparent attempts by African American musicians to preserve and interpret these songs. ${ }^{36}$ Whether or not white audiences recognized the musical innovations that African American spirituals in films represented, their effect was to capture a particular portrait of African American religious existence that was "classical" in its association with the pastoral songs and people of the American South who echoed a long African past and the general association of African Americans with an innate, simplistic Christian religiosity. 
While the choir's performance of this music in Ellington's short film represented, in actuality, modern musical innovations, their presence and singing served to play on and reinforce popular white (and black) images of an inherently-and preferably-static African American religion of an older era.

It is important to note that this choir of shadows in the final scene of Ellington's Black and Tan was the Hall Johnson Choir, formed in 1925 by Hall Johnson, the son of an African Methodist Episcopal (A.M.E.) minister and alumnus of several university music programs, including the Institute of Musical Art, the predecessor to Julliard. According to Weisenfeld, Johnson and his choir were known for "complex and spirited renditions" of African American spirituals. In the 1930s and 1940s, Johnson's spirituals became "so closely associated with representations of black religion in American film" that his vocal arrangements appeared in most of the era's major African American films, namely, The Green Pastures (1936) and Cabin in the Sky (1943). ${ }^{37}$ This choir's inclusion in Ellington's film demonstrates the concerted efforts of black filmmakers, musicians, actors, and actresses invested in narratives of African American artistic respectability, but those efforts were reliant on established cultural notions of black religiosity that often ran counter to progressive social projects.

Alongside the presence of a spiritual and a choir famous for performing such music, Ellington's own religious music in the film depended on his musical knowledge of European classical music in addition to spirituals and the blues. As Fredi Washington is ailing, she tells Ellington, "Duke, play me the 'Black and Tan Fantasy.'” According to Janna Tull Steed, an overall twelve-bar blues structure frames this Ellington composition while it also contains melodic references to Frédéric Chopin's "Funeral March," ultimately climaxing with the most recognizable phrase of this classical sonata (it is at this point that Washington passes away). ${ }^{38}$ The film's particular arrangement of "Black and Tan Fantasy" also includes the Hall Johnson Choir swaying and providing spiritual lyrics for the tune, singing "ding, dong ... hear the bells ding, dong-ing, in my ear" as Fredi awaits death and moaning of "Lord, Lord" after her passing. This mixing of Ellington's "modern" jazz and the "classical" religious musical genres allowed for a popular perception of an "old-time" African American religiosity, ultimately confronting the very modern individual at the end of her life. ${ }^{39}$

\section{"Come Sunday"}

According to the original script for Ellington's 1943 performance of his symphonic composition Black, Brown, and Beige, the 
composer began to tell the audience the history of African Americans through the mythical journey of Boola, an enslaved African who travels through three hundred years of history, including the African slave trade, the colonial era, Emancipation, the "Black Metropolis" of Harlem, and World War II. ${ }^{40}$ Boola's experience on a southern slave plantation in the composition's first section, "Black," captures African American religiosity in the Sunday experiences of black slaves. Ellington's poetry introduced the audience to spirituals by detailing the peace slaves sought against the lashes of their forced daily labor:

Came Sunday. Boola was irresistibly drawn

To that pretty white house with the steeple

So tall, shining there in the sun. Everyone

Who entered there was scrubbed and polished

And all dressed up! How happy they seemed!

When the white voices inside rang out

In triumph... the blacks outside would grunt

Subdued approval. When the white voices inside

Were raised in joyous song, the blacks outside

Hummed along, adding their own touches. Weaving

Gorgeous melodic, harmonic, rhythmic patterns.

Thus the spiritual was born. Highly emotional

Worshipping of God in song. ${ }^{41}$

An early manuscript version of Ellington's introduction detailed the composer's impression of enslaved black religious life on southern plantations, providing the imagery of religiously receptive African American slaves "huddled" beneath a tree. The slaves whispered the Word of God to each other, each of them "sipping the reverent purity / Of each trembling word till he was filled / To bursting with the joy it brought!" Ellington emphasized the enslaved blacks' embodied religiosity in their conflicted responses to hearing the white worshipers proclaim the Christian gospel, simultaneously restraining their expressive, emotional reverence for God and identifying the moral hypocrisy of their enslavement:

Thrilling, puzzling, strange it was...

They spoke of love of all mankind....

What then was this? Did they not hear:

"A false balance is abomination to the Lord;

But a just weight is his delight." ...

"When pride cometh, then cometh shame;

But with the lowly is wisdom."

"The integrity of the upright shall guide them: 
But the perverseness of transgressors

Shall destroy them."

In turn they trembled for the transgressors, Their joy knew no bounds when words of hope Renewed in them their faith and trust in God.

HUSH! Don't shout about it! No! No!

Keep it down! Down! Enjoy your sweet suffering

Of this profound upheaval of love and joy

In aching silence.... ${ }^{42}$

As the enslaved blacks "trembled" in "aching silence" over the prospect that their white "transgressors" would one day meet some form of divine justice, the joy that they embodied (and had to subdue in the presence of white Christian masters and mistresses) represented, for Ellington, an essential African American religious response to the material and spiritual freedom that they understood the biblical scriptures promised them. And with his gifted ability to sing the spirituals like no one else, Boola, who personified African American history, represented how a race's inherent and steadfast religiosity allowed it to endure the suffering of Jim Crow inequality following Emancipation.

"Come Sunday," originally an instrumental composition, stands as Ellington's musical rendering of the history of these "soothing" spirituals in black America. When Ellington recorded "Come Sunday" for a 1958 album version of Black, Brown, and Beige, he recruited gospel singer Mahalia Jackson, who sang lyrics that captured the notion of African American reliance on God in the face of daily hardships: ${ }^{43}$

Lord, dear Lord of love, God almighty, God above Please look down and see my people through.

Lord, dear Lord of love, God almighty, God above Please look down and see my people through.

I believe the sun and moon will shine up in the sky When the day is grey, I know it's clouds passing by. $\mathrm{He}^{\prime} 1 \mathrm{l}$ give peace and comfort to every troubled mind Come Sunday, oh, come Sunday, that's the day.

Often we'll feel wearied, but He knows our every care Go to Him in secret, He will hear your every prayer. Lilies of the valley, they neither toil nor spin And flowers bloom and spring time birds sing.

Often we'll feel wearied, but He knows our every care Go to Him in secret, He will hear your every prayer. Up from dawn 'til sunset, men work hard all day Come Sunday, oh, come Sunday, that's the day. ${ }^{4}$ 
The first stanza of "Come Sunday" illustrates the individual's appeal to God for the protection of an entire race. The next stanza turns toward a spiritual rendering of the natural world, one in which the symbols of sustenance and guidance ("the sun and moon") can be depended on to reappear, even when that provision seems obscured (in this case, by heavy overcast). God's gift of "peace and comfort"when Sunday comes-exists for enduring the psychological devastation of a people's existence in America, less to heal the wounds of the physical traumas of slavery and Jim Crow segregation. With the third stanza, God is for these people an intimate confidant, aware of life's woes and interested in listening to the individual who elects to give voice to suffering. Ellington then references in the Christian gospels the instructions Jesus gave his disciples that they must not worry about tomorrow's provisions, that they should take lessons from natural flora and fauna, and that they should instead "strive first for the kingdom of God and his righteousness." 45 The last stanza speaks to the specific daily reality of enslaved labor-an experience soon replicated in the dawn-to-dusk workdays of black sharecroppers postEmancipation-and the final line captures the African American slave's anticipation of the one day of respite promised by the antebellum South's Protestant religious culture.

With "Come Sunday," Ellington captures the universally familiar in the weariness of daily labor. However, he presents this common experience in (and for) a particular racial story: this is the narrative of a compensatory African American Christianity, an expression of the belief that the divine assuages the spirit in response to how the society abuses the body. Here, Ellington's reverential musical portrait frames African American religious history as a set of well-established cultural practices. To consider African American religiosity is, for Ellington, to think deeply about a history of alwaysenduring ancestors, and one may appeal to the same religious concepts as they had when one faces the world's travails. Weariness with the world's ills finds its salve on Sunday.

Whereas Ellington's 1943 poetic introduction to the spirituals celebrated the improvisational creativity of his ancestors in the face of hardship and exclusion, his later 1958 lyrics relegated a concept of religious experience to the weekly practice of a racialized memorialization, in which the mode of being religious revolves around thinking about one's racial ancestors as they were religious. The construction of these lyrics echoes what Paul A. Anderson identified as Ellington's embrace of "the [Harlem] Renaissance project of memorializing the black folk inheritance. ${ }^{\prime 46}$ For the listener, Ellington's music and lyrics stir up romantic, pastoral imaginations of long-suffering African 
Americans. It seems, therefore, that the utility of one's religious life is in the individual's capacity to think fondly and reverently on the faith of one's mothers and fathers and to practice their brand of piety in order to endure society, and one may entertain that idea of reliefonly, apparently_come Sunday. Understood in this light, the irony of Ellington's "Come Sunday" is that its lyrical content suggests that African American religiosity is essentially traditional and customary, even though the music both represents musical innovation and celebrates African American innovativeness in history. For Ellington, the individual practices religious devotion by taking one's woes to the divine for relief once a week - and not much else. There is no room to capture prosaically or lyrically, for instance, more than a century of (in)visible institutional practices and spaces of theological training, professional education, or political activism in African American religious history. They are implicitly nonessential to the history and practice of African American religion-likely so because this jazz musician's early life and career did not require that he spend time in any of these contexts. Ultimately, black innovativeness sounds modern; black religion feels classical.

\section{Echoes of a Folk Preacher: Ellington's "Secular" Black Sermons}

In 1927, the multifaceted writer and activist James Weldon Johnson wrote God's Trombones: Seven Negro Sermons in Verse to capture what he called the "folk sermon," the particular African American sermonic style of the "old-time Negro preacher" in the American South. Johnson's seven poems captured the memory of his "boyhood sermons" and reflected for him an identifiable tradition of African American preaching that seemed to persist into the early years of the twentieth century. Fearing (and expecting) the eventual passing of this sermonic tradition, Johnson sought to capture in writing the feel of this traditional African American male preacher. The preface to God's Trombones identifies this social figure's typical rhetorical hallmarks:

The old-time Negro preacher of parts was above all an orator, and in good measure an actor. He knew the secret of oratory, that at bottom it is a progression of rhythmic words more than it is anything else. Indeed, I have witnessed congregations moved to ecstasy by the rhythmic intoning of sheer incoherencies. He was a master of all the modes of eloquence. He often possessed a voice that was a marvelous instrument, a voice he could modulate from a sepulchral whisper to a crashing thunder clap. His discourse was 
generally kept at a high pitch of fervency, but occasionally he dropped into colloquialisms and, less often, into humor. He preached a personal and anthropomorphic God, a sureenough heaven and a red-hot hell. His imagination was bold and unfettered. He had the power to sweep his hearers before him; and so himself was often swept away. At such times his language was not prose but poetry. ${ }^{47}$

As the title indicates, the "marvelous instrument" of this preacher was, for Johnson, the trombone, "the instrument possessing above all others the power to express the wide and varied range of emotions encompassed by the human voice-with greater amplitude." ${ }^{48}$ Johnson regarded the folk sermon as a primarily oral tradition, and it was the responsibility of black artists-in his case, poets-to consider the sermon as much a part of African American folk culture as sacred and secular songs, dances, and plantation tales.

For the folk sermon, the concern was whether or not to write in southern black dialect. Johnson resisted this practice, calling instead for a set of literary strategies to preserve "the racial spirit by symbols from within rather than symbols from without." His concern was that to use dialect was simply to signify the "errors" of black English rather than to be truly charitable to an oral sermon's form and content, for, according to literary scholar Marcellus Blount, white dialect writers at the turn of the century often "undermine[d] the authority of their black speakers by casting them as objects of cultural distortion and ridicule" through this transcription style. ${ }^{49}$ Johnson wrote: "[The Negro poet] needs a form that is freer and larger than dialect, but which will still hold the racial flavor; a form expressing the imagery, the idioms, the peculiar turns of thought and the distinctive humor and pathos, too, of the Negro, but which will also be capable of voicing the deepest and highest emotions and aspirations and allow the widest range of subjects and the widest scope of treatment." ${ }^{50}$

\section{"Is That Religion?"}

In 1931, Ellington recorded a cover of "Is That Religion?" a comedic criticism of sexual impropriety in black religious houses of worship written by African American composer Maceo Pinkard and Jewish American lyricist Mitchell Parish. ${ }^{51}$ This composition entered a culture where images of black preachers and churchwomen were the constant fodder of comedic portraits, and African American music scholar Teresa L. Reed notes that, for a popular audience, this tune, sung by a preacher in "a highly theatrical, burlesque singing 
style," helped to reinforce the stereotype of African American churches as "place[s] not of devotion but of unbridled sexuality." ${ }^{22}$ The short tune opens with the Ellington Orchestra, followed by the preacher's message to his congregation:

Brethren
Sisteren
Hear my preachin'
Hear my preachin', do!
Brethren
Sisteren!
The Good Book teachin'
Ain't been reachin' you!

Now sisters just strut the aisle

All dressed to kill with style

You wink your eye and smile

Is that religion?

One thing I do despise

You catch my deacon's eyes

And that's where the weakness lies

Is that religion?

You see, your parson's vexed

And you've got him so perplexed

That his mind ain't on his text!

Now, tell me, is that religion?

There's some cheatin' gonna be did

And you all done took off the lid

Tryin' to get your parson to skid Is that religion $?^{53}$

The luxury of technological innovation allowed for sound recordings to expand the modes of reproducing folk culture. At the same timeas Johnson warned literary artists-it allowed musicians and comedians to reproduce stereotypical notions of African American dialect preaching and religious life, as captured in this Ellington version. The preacher gives "Brethren" an English parallel in "Sisteren" as he stresses and stretches it out. This allows for the listener to become amused by the lack of proper English and to signal suspicion about the minister's scruples. But his emphasis also signals that the preacher intends to direct most of his ire at black churchwomen, whom he deems responsible for black religious men's temptation.

The second stanza affirms this portrait of a typical Sunday service-it is the black women who have neither the sense for proper attire in a religious setting nor a grasp of the fact that black men's eyes are constantly upon them. These women exist as fashionable objects 
of desire. The sermon in this tune suggests a scene where young black women move around the church all throughout the service, tempting black men of all ages as they pass by, since they lack the proper sense to remain seated and focused on more religious matters. The preacher can empathize with the deacon, noting his "weakness" for beautiful women.

The third stanza indicates that these black women interrupt the possibility for the preacher to convey to the congregation a genuine, religious sermon-consequently, this preaching moment cannot represent true religiosity but only a necessary excoriation of the congregation. The preacher is unable to focus on his text-either his prepared sermon or a simple passage of scripture. Because of these young black temptresses, he guarantees that sexual impropriety will occur (and the listener may assume that this preacher does not exclude himself from this prophecy). Along with their revealing attire, this preacher informs the churchwomen that they have exposed the constant desire in the black congregation as well as in those church folk who participate in untoward behavior. The preacher insists that these women must want his sexual advances ("Tryin' to get your pastor to skid") since they must know how their attire appeals to men.

Ellington's decision to record "Is That Religion?" was his affirmation, with a popular jazz tune, that there was an absence of genuine, moral Christianity in contemporary African American church life. This song is a comical piece of music; however, it does nothing to encourage a popular (white or black) audience to hold contemporary black Christianity in high esteem, particularly as it stands in the care of wayward and unlettered black preachers, desirable and inattentive young black women, and black churchmen of all ages. Additionally, older African American churchwomen are nonexistent in this tuneeither they are the "church mothers" beyond moral reproach and color his depiction of true African American religion or they are simply not the preacher's objects of desire. The thirty-two-year-old Ellington certainly assents to the narrative of a contemporary black church life that has fallen from grace-modern religious folk appear not to capture the reverential sensibilities of the "true" religion of their forebears, especially that of his youth. Nostalgia for the religious atmosphere of Ellington's black middle-class adolescence appears to preclude any charitable portrait of contemporary African American religiosity.

\section{"My People"}

Over the next four decades, audio recording technology advanced steadily with the growth of the popular music industry, 
increasing both the recording quality and the length of sound tracks on a single record. Ellington the musician benefited from the opportunities to reproduce his musical conceptions of culture in ways James Weldon Johnson only imagined, having passed away in 1938. In 1963, a late-career Ellington composed a stage play, My People, a "social significance" work intended for a children's audience-reminiscent of the pageants from Ellington's childhood such as Du Bois' The Star of Ethiopia. ${ }^{54}$ This work reflected the significance of the height of the civil rights era, and Ellington's play was broadcast so that African American children, the larger white American viewership, and a wider European audience would know that "there are Negro doctors, lawyers, businessmen, nurses, teachers, telephone operators, policemen, and housewives" worthy of admiration. ${ }^{55}$ The album version's title track, "My People," features Ellington in a preacherly conversation with an African American audience, echoing black "phonograph preachers" such as Rev. James M. Gates, whose recorded sermons shaped modern black Protestant cultural production in the 1920 s and 1930s: ${ }^{.6}$

My people. [Congregation:] (Yeah!) My people! (Yeah, Preach!) Singin', Dancin', Prayin', Thinkin'. (Amen) Talkin' about freedom! (Yes, indeed!) Workin'! (Oh, hard too.) Building America into the most powerful nation in the world. (Tell it, Talk about it.) Cotton. Sugar. Indigo. Iron! (Rice) Coal, peanuts, steel, the railroad, you name it! (Tell 'em like it is.) The foundation of the United States rests on the sweat of my people! (Tell it! Tell it!) And in addition to workin' and sweatin', don't ever forget that my people fought and died in every war! (Help him! Right.) Every enemy of the USA has had to face my people on the front lines. (My Lord. Face to face! For days! Tell 'em about it.) Yes, and when Teddy Roosevelt led his Rough Riders up San Juan Hill in the Spanish American War, (Well? Dig!) for the first time, my people returned home decorated heroes. (Heroes! All Right! Preach! Tell it!) [Applause] They had won another war for Uncle Sam! (The truth! Yes!)

Ellington's sermon captures what Blount identifies as "verbal performance viewed as a cultural event." Ellington dramatizes the relationship between preacher and congregation, demonstrating "the performance of perfect continuity between artist and audience. ${ }^{\prime 57}$ The preacher and the audience exist as co-creators of a sermonic narrative of African American history in this "call-and-response" practice. The congregation does more than simply respond to Ellington's building narrative with affirmation-they repeat the words he emphasizes, 
they solicit his elaboration of the story, they add elements (e.g., rice) to the narrative he provides as a supportive strategy and recognition of their familiarity with the narrative, and their affirmation allows him momentarily to increase the speed of his cadence. At times, they are purely antiphonal: they anticipate a salient point by Ellington and wait until his vocal inflection signals a sentence's end to provide a pure, uninterrupted response. At other moments, they perform a humming and murmuring countermelody for Ellington's preaching; although their collective speaking is indiscernible, it is doubtless a forceful support of his message at that moment. Ellington's driving sermonic narrative and the verbal punctuations of his audience define the sermon as a rhetorical space where silence is drowned out by constant conversation. This is a narrative to be enjoyed. The result is, in a black congregational context, one generation of preachers and vocally active congregants teaching younger generations how to participate in this mode of narrative performance, in other words, how to become co-creators of a sermon.

But the content of this sermon adds another story: Ellington captures the folk preacher's rhythms and intonation as well as the congregational sounds of a sermon without its expected theological content. This is the story of empire and industry, with the involvement of African Americans given paramount significance. The United States and Western European states as superpowers would not exist without the history of fettered African labor, and this is certainly an opportunity for Ellington's white fan base (in America and Europe) to hear the specific cultural celebration of African Americans asserting how essential they have been (and continue to be) in economic and geopolitical affairs. African American preachers and public speakers alike affirmed the resilience and survival of their people, but it is peculiar that the seemingly "religious" responses of the congregation affirm Ellington's narrative of the Western world's growth and expansion that does not invoke notions of African American religious fidelity to the divine. Ellington's object of reverence is the African American people; the historical narrative of their resilience and ever-present involvement in Western progress is the only transcendent concept he and the congregation praise. Is it possible to read Ellington's folk "sermon" as more a story of the vocally engaged black audience than of the messenger? Does he affirm the notion of an African American populace's essentially "religious" response to any narratives they affirm? In any case, through this sermonic interaction, Ellington sells to a wider audience a very modern, ostensibly nonreligious message about the historical narratives African Americans maintain, build upon, and affirm at the same time that he also sells 
the portrait of an African American folk (as represented in this congregation) as essentially-and classically-religious. ${ }^{58}$

But the sermon continues. Ellington's historical narrative transforms into the celebration of black musical creativity, and it roots that creativity in the relatable dramas of his people's mundane existence:

Now, a decorated hero is a symbol of glamour. (Right? Right?) And glamorous heroes are attractive. (Oh yeah! For days!) And so, being attractive, some of them attracted other men's women! (Uh oh!) Huh? And on the other hand, some heroes returned home to find that while they were gone, somebody had attracted their women. (Whoops! No good! Oh, mercy!) And right after that came the blues. (Oh yes!) The blues. The hero, the hero's woman, the husband of the hero's girlfriend, the girlfriend. (Wait a minute, you lost me, brother!) Each one was eligible for the blues. (Deep!) And the one to get the blues was always the one left out (Out.) on the odd corner of that romantic triangle. (Believe it! That love triangle's tough!) And as W. C. Handy might have said: (Tell us! What'd he say?) The blues is the accompaniment [finger snaps begin] to the world's greatest duet, a man and a woman goin' steady. (Uh huh!) The blues is the accompaniment to the world's greatest duet, a man and a woman goin' steady. (Mmm hmm!) And if neither one of them feels like singin' 'em, (Yeah?) then the blues just vamps 'til ready. (Believe it! Yes you did!) $[\text { Music }]^{59}$

Ironically, African American success in the Western world-defined by the status of black men as military heroes—created the blues, first as a despondent reaction to unrequited love and then as a cherished American musical genre. The congregation is more comical in this portion of Ellington's sermon, unable to anticipate his longer thoughts at times, and one member audibly becomes confused by the preacher. Nevertheless, the spirit of their responses persists as the echoes of an African American religious tradition, but the sermon's subject matter-romance and the blues-represents anything but an appropriate topic for a worship setting. This is Ellington's celebration of military heroism, the romantic entanglements it brings-and it is unclear whether Ellington refers to interracial coupling or simply African American lovers-and the blues, a musical genre that flourishes upon life's brokenness and bawdiness rather than its joyousness and propriety. But it is again clear that Ellington's reverence is for a people instead of a god, and humorously so. His congregation vocalizes their intimate familiarity with the blues (no less what 
produces it), and they afford this aspect of life the same affirmation they may provide the spirituals. These people are Ellington's folk, receptive to his narrative celebrating African American history, all the while essentially and unceasingly religious in the content and form of their responses to life. ${ }^{60}$

\section{Conclusion}

To take seriously the African American musician as intellectual would mean recognizing that musical choices, both socio-structural and content oriented, are acts of a mind at work. The actions that are the culmination of such choices may be self-conscious or inadvertent attempts at leadership. One need not articulate an artistic philosophy in the pages of Phylon or Liberator in order to have one. Neither does one need to read such a philosophy in the pages of a cultural journal to recognize ideas at work in the art itself.

-James C. Hall, “The African American Musician as Intellectual" ${ }^{11}$

What is at stake in understanding early-twentieth-century portraits of African American folk religiosity? Why is it necessary to examine popular musicians and their compositions for the constructions of culture they (re)produce? There are stories of culture, history, and religious expression to uncover in everyone's historical, racial, and religious contexts, and, if one ignores the degree of thought involved in crafting music, she or he ignores the thought that musicians produce and the social perceptions and attitudes those thoughts reinforce. Through short film in the 1920s, comical popular song in the 1930s, long-form symphonic movements in the 1940s, lyricism in the 1950s, and dramatic prose in the 1960s, Duke Ellington engaged in a project of racial uplift and respectability, and he sought, like many other artists in the Harlem Renaissance, to make white America and the rest of the world aware of the beauty of blackness. His own faith can be situated in a tradition of African American narratives of culture that incorporated "classical" narratives of world history to construct a sympathetic image of a black "folk." But Ellington also practiced a nostalgia for a religion and people that relied on narratives of African American religiosity frozen in time (the past) and space (the pastoral South). The social work of his progressive musical projects clashed with the ideas upon which it depended, and this ultimately entailed unintentional consequences for representing racialized and gendered subjects. A reliance on the nostalgic memories of African American religiosity and 
well-established histories of African-descended peoples seemed to preclude any engagement with contemporary forms of black religious expression wherein religious "innovations" might have appeared politically progressive or socially engaged. After the major legislative successes of the 1960s-the Civil Rights Act of 1964 and the Voting Rights Act of 1965-Ellington re-engaged a much more ecumenical portrait of Christian religiosity in his three "Sacred Concerts," which spoke to his continued celebration of African American social strides as well as the prospect of an interracial future. But before those successes, it seems that the jazz composer and musician sought to articulate musically a more static and solely compensatory structure for black religious life and practice.

A fundraising benefit produced the album Goin' Home-A Tribute to Duke Ellington/A Benefit for the Duke Ellington Foundation, released in 2001. In this recording of "Come Sunday," however, the following lyrics took the place of the original third and fourth stanzas:

I believe, I believe God is now, was then, and always will be (always will be)

With God's blessings, we can make it through eternity (through eternity)

Lord, dear Lord above, God almighty, God of love

Please look down and see my people through. (2x)

They're all dressed up this morning, they've been working hard all week long, yeah

Glory, Hallelujah, come Sunday, they can take it to God's throne.

If we keep God in our lives, then I know that

Sunday can be every day.

Come Sunday, they teach us, to do unto others as you would have them do unto you.

That's the Golden Rule, yeah.

Please look down and see my people through. (Early Sunday morning) (2x)

These updated lyrics at the turn of the twenty-first century appear to represent a reinterpretation of Ellington's original piece, one that shifts the focus away from simply an appreciation of worshipful black Christian ancestors in the slave era. Instead, they indicate a shift toward a modern sense of God's presence in the everyday working lives of African American Christians. Sunday is not simply a day of relief from forced toil-rather, to live every day as Sunday is to carry a sense of God's presence and guidance of the individual's life throughout the work week. Unlike in Ellington's original lyrics, there 
is the prospect of an eternal reward for religious devotion (where every day is a Sunday to enjoy God's presence). The purpose of these lyrics is to preach a standard of religious devotion rather than serve as a musical meditation on divinely guided racial history. They may not even reflect a religious message about or for just African American Christiansthey reflect the approach to living a Christian life emblematic of contemporary mainstream American evangelical teachings. Overall, the lyrical changes reflect religious sentiments that would not quite match Ellington's own.

How might we understand the ways in which individuals construct or rely upon the culture of a people to produce changes in social attitudes? And in the process, how might these individuals rely on and recreate stereotypes of that culture and its living people, those represented who do not have the same public voice as a major musician? Popular culture presents various opportunities to locate, in Weisenfeld's words, the "coupling of religion and race" as it "authorizes and naturalizes American racial categories and works to describe and prescribe the boundaries of the category of religion." ${ }^{\prime \prime 2}$ When we make the effort to raise the work of musicians such as Duke Ellington to critical inquiry, we may be able to understand better the forms that racial and religious representations take and how they are propagated for wider audiences.

\section{Notes}

I am grateful to Wallace Best, Kwami Coleman, Judith Weisenfeld, and the participants in the 2011-2012 American Religious History Workshop at Princeton University for their encouragement and critical feedback on earlier versions of this article.

1. Duke Ellington, "Black, Brown, and Beige" script, undated, in Ruth Ellington Collection, 1940-1991, Series 6-Lyrics, Scripts, and Notes, box 7, folder 5, Archives Center, National Museum of American History.

2. Duke Ellington often announced the latter song as "Billy Strayhorn's 'Take the " $\mathrm{A}$ " Train,'" citing his co-composer responsible for authoring this and other tunes often attributed solely to Ellington.

3. See the works of Ellington scholars Mark Tucker, Janna Tull Steed, and Harvey G. Cohen. I intend to focus here on works Ellington composed primarily during his highest commercial popularity.

4. Judith Weisenfeld, Hollywood Be Thy Name: African American Religion in American Film, 1929-1949 (Berkeley: University of California Press, 2007), 5-6. 
5. A "classical" African American Christianity was not necessarily primitive in Ellington's rendering because he did not depict black Christians as a primitively religious people. In contrast, his musical depictions of pre-Christian enslaved African religiosity and West African drumming and rhythm (regarded as the progenitor of modern American music) reflected his notion of their primitive sensuousness. Ellington introduced his 1940 composition "Ko-Ko" at his 1943 Carnegie Hall concert as "a little descriptive scene of the days that inspired jazz ... think it was in New Orleans, and a place called 'Congo Square' where the slaves used to gather and do native and sensuous dances, religious dances." But, seemingly in response to criticisms of primitivist representations of African-descended peoples and their history, Ellington even qualified his usage of the word "primitive." In the 1956 musical allegory A Drum Is a Woman, he narrated the journey of Madam Zajj, the personification of rhythm, as she traveled throughout the world. On the track "Congo Square," Ellington declared, "One by one, every head turns to the entrance of the most primitive woman. / This, of course, does not mean simple or elementary. / She is an exciting, ornately stimulating seductress with patterns of excitement and the power to hypnotize and enervate the will toward total abandonment. / This, if anybody, must be none other than Madam Zajj." I consider this descriptive attempt to render "primitive" African-derived rhythms as foundational, complex, and bearing efficacious sway over bodily responses to be Ellington's method of divesting them of negative connotations and signifying their consequential historical presence, although they maintain persistent social and cultural complications that accompany this descriptor (not to mention the feminine gendering of rhythm versus the presumed masculinity of the person producing/in possession of the rhythm). Ultimately, Ellington's descriptive work serves to make sophisticated a category often deployed to deride African and African American people and culture.

6. Nathan Huggins, Harlem Renaissance, updated ed. (New York: Oxford University Press, 2007), 10-11.

7. Ibid., 77.

8. George Hutchinson, The Harlem Renaissance in Black and White (Cambridge: Belknap Press of Harvard University Press, 1997), 182.

9. Huggins, Harlem Renaissance, 10-11.

10. John Howland, "Ellington Uptown": Duke Ellington, James P. Johnson, and the Birth of Concert Jazz (Ann Arbor: University of Michigan Press, 2009), 55-56. Locke; The Negro and His Music, 94-98. 
11. Mark Tucker, "The Renaissance Education of Duke Ellington," in Black Music in the Harlem Renaissance, ed. Samuel A. Floyd, Jr. (Westport, Conn.: Greenwood Press, 1990), 112.

12. Huggins, Harlem Renaissance, 72-73.

13. Hutchinson, The Harlem Renaissance in Black and White, 182-84.

14. Duke Ellington, "The Duke Steps Out," Rhythm, March 1931, 20-22.

15. “Duke Ellington Defends His Music," Sunday Post, July 1933.

16. Gama Gilbert, “'Hot Damn!' Says Ellington When Ranked with Bach," Philadelphia Record, May 17, 1935.

17. Florence Zunser, "'Opera Must Die,' Says Galli-Curci! Long Live the Blues!" New York Evening Graphic Magazine, December 27, 1930, 45.

18. Mark Tucker notes that Ellington reflected often on the "Negro history" he learned as a student, a type of learning about race pride modeled on Carter G. Woodson's historical project. Musicians who kept alive the tradition of the spirituals, such as Eva Jessye, were also essential to signifying African American religion in a dated, "folk" light at the same time they wished to preserve this tradition as a "classical" form.

19. Ellington, "The Duke Steps Out."

20. Ibid.

21. Eric Porter, What Is This Thing Called Jazz? African American Musicians as Artists, Critics, and Activists (Berkeley: University of California Press, 2002), xvi.

22. W. E. B. Du Bois published The Philadelphia Negro in 1899 as a response to his fellow University of Pennsylvania faculty, who asked that he prove, "on an academic basis," that African Americans were responsible for the "bad government, prostitution, and criminality" in Philadelphia. Most black Philadelphians lived in the city's seventh ward, and Du Bois collected data on their living conditions and habits over the next fifteen months. Du Bois's specific findings on African American church cultures were linked to an historical assessment of black religion in America in his 1900 essay "The Religion of the American Negro." In this essay, Du Bois asserted a natural religiosity for African Americans in attempting to explain the mass acceptance of Christianity by black slaves. Du Bois stated, "The Negro has already been pointed out many times as a religious animal - a being of that deep emotional nature which turns instinctively toward the supernatural. Endowed with a rich tropical 
imagination and a keen, delicate appreciation of Nature, the transplanted African lived in a world animate with gods and devils, elves and witches." Du Bois made this historical case to then assert that there was a new type of African American, living in northern cities, who signaled the end of the older, naturally religious type who held onto the "vague superstitions" of an African past (and this latter type was to be found among the "unlettered" blacks, mostly in the South). This new, more cynical African American in northern cities left the churches for gambling halls and enjoyed the more "sensual" vices in addition to criminality. Du Bois's sociological outlines of the condition of African Americans in the North and South - the North representing black cynicism and vice with its loss of "religion" as the superstitious and ecstatic, the Southern blacks capturing that "authentic" religiosity—served a definite political purpose: the highlighting of social conditions, the types of human beings these social conditions produced, and their prospects for fuller incorporation into American civilization. Social change, for Du Bois, would elevate the Negro in the South beyond a reliance on unenlightened forms of religion and curb the urban immoralities of the northern Negro, for both were pathologies-in Du Bois's mind-stemming from the history of slavery and of living amid Jim Crow inequality. By treating African American religion as a subject of academic inquiry, Du Bois inaugurated a tradition of study that challenged sociology's sole dependence on "empirical" observations of people and subsequent analysis by incorporating their cultural productivity into discussions of social policy. According to his autobiography, Du Bois committed to the collection of facts for formulating public policy while vested in black social justice: "I was going to study the facts, any and all facts, concerning the American Negro and his plight, and by measurement and comparison and research, work up to any valid generalizations which I could." See W. E. B. Du Bois, "The Religion of the American Negro," in W. E. B. Du Bois: On Sociology and the Black Community, eds. Dan S. Green and Edwin D. Driver (Chicago: University of Chicago Press, 1978), 220; Curtis J. Evans, The Burden of Black Religion (New York: Oxford University Press, 2008), 154; W. E. B. Du Bois, Dusk of Dawn (New York: Schocken Books, 1968), 51.

\section{Porter, What Is This Thing Called Jazz? 3-4.}

24. Du Bois stressed the idea that a different cultural character was developing in the urban North than what he observed in rural black religious communities. His characterization of religion in the South was fleshed out most famously in The Souls of Black Folk in 1903, primarily in the chapter "Of the Faith of the Fathers." It was in rural religious spirituals and ecstatic religious practices (which he termed "the frenzy" in his study of a Christian revival service) that Du Bois essentialized a religious 
character for African Americans. Spirituals-religious songs created by black slaves-were "the most original and beautiful expression of human life and longing yet born on American soil." These songs came from "African forests, where [their] counterpart can still be heard," and the "tragic soul-life" of American slavery shaped their contemporary content as "the one true expression of a people's sorrow, despair, and hope." See W. E. B. Du Bois, The Souls of Black Folk (New York: Modern Library, 2003), 192.

25. Edward K. Ellington, Music Is My Mistress (Garden City, N.Y.: Doubleday, 1973), 12-15.

26. Tucker, "The Renaissance Education of Duke Ellington," $117-18$.

27. Ellington, Music Is My Mistress, 17.

28. Harvey G. Cohen, Duke Ellington's America (Chicago: University of Chicago Press, 2010), 338-39, 449; Ellington, Music Is My Mistress, 113; Theodore R. Hudson "Duke Ellington's Literary Sources," American Music (Spring 1991): 23.

29. See Laurie Maffly-Kipp, Setting Down the Sacred Past: AfricanAmerican Race Histories (Cambridge: Belknap Press of Harvard University Press, 2010), 35-36, 223-24. For some examples of this prevalent theme in African American Christianity, see the Reverend James Morris Webb's The Black Man, The Father of Civilization, Proven by Biblical History (1919) and Drusilla Dunjee Houston's Wonderful Ethiopians of the Ancient Cushite Empire (1926). Additionally, the African Methodist Episcopal Zion's Star of Zion weekly newspaper published a "Questions and Answers in Negro History" column in 1925 by George Wells Parker, who wrote on the topic of African presence in ancient civilizations (most notably, a pamphlet titled Children of the Sun) and co-founded the nationalist organization, Hamitic League of the World.

30. John Franceschina, Duke Ellington's Music for the Theatre (Jefferson, N.C.: McFarland and Co., 2001), 167; Maurice Peress, "My Life with 'Black, Brown, and Beige'" Black Music Research Journal (Autumn 1993): 153.

31. Don George, Sweet Man: The Real Duke Ellington (New York: G. P. Putnam's Sons, 1981), 187-88.

32. See Cohen, Duke Ellington's America, 102-5.

33. Janna Tull Steed, Duke Ellington: A Spiritual Biography (New York: Crossroad Publishing, 1999), 53-54. 
34. James Weldon Johnson and J. Rosamond Johnson, The Books of American Negro Spirituals, 2 vols. (New York: Viking Press, 1925/1926), 13.

\section{Ibid.}

36. Weisenfeld discusses early-twentieth-century arranger, composer, and conductor of religious music, Eva Jessye: "Whereas Du Bois saw spirituals as 'redemptive fragments of a fading stage of folk life' that needed to be given place of distinction in African American cultural memory, Jessye believed their dramatic performance to be a critical tool in the social, political, and spiritual development of African Americans." See Judith Weisenfeld, "Truths That Liberate the Soul': Eva Jessye and the Politics of Religious Performance," in Women and Religion in the African Diaspora: Knowledge, Power, and Performance, ed. R. Marie Griffith and Barbara Dianne Savage (Baltimore: Johns Hopkins University Press, 2006), 224.

37. Weisenfeld, Hollywood Be Thy Name, 61.

38. Steed, Duke Ellington, 53.

39. This is my best interpretation of the Hall Johnson Choir's lyrics while the Ellington band plays. Steed writes, "The choir continues to sing, seeming to intone the sound of church bells or a repeated two-word phrase that is indiscernible." Steed, Duke Ellington, 54.

40. The Black, Brown, and Beige premiere concert in 1943 at Carnegie Hall featured preview pieces in Down Beat magazine and the New York Times Magazine. Following the premiere, largely negative reviews characterized the highly anticipated, long-form work as an unfortunate departure from the "authentic" jazz of Ellington's earlier, shorter dance compositions. Mixed reviews criticized the "Black" movement (which contained the instrumental "Come Sunday") but appreciated "Brown" and "Beige." Some criticism rested on the Ellington orchestra's performance that night, others on the supposed pretentions of Ellington himself. Attendant with the emergence of professional jazz criticism, debates over Ellington's performance and composition persisted into the 1970s as he came to occupy a seat in the jazz pantheon and as critics and musicians discerned his stylistic and compositional influences upon subsequent jazz artists. The first article analyzing the musical structure of the entire work, based on various recordings and transcriptions, appeared in the British journal Jazz and Blues in 1974. See Mark Tucker's compilation of Black, Brown, and Beige criticism in The Duke Ellington Reader, ed. Mark Tucker (New York: Oxford University Press, 1993), 153-204. 
41. Leonard Feather and Maurice Peress, Liner Notes to Duke Ellington, Black, Brown, and Beige, Louie Bellson and His All-Star Orchestra, Jazz Heritage Inc., 513633L, 1994, compact disc. Harvey Cohen provides a slightly different version of this introduction from an undated and unpublished narrative sketch (ca. late 1942 / early 1943): "Came Sunday. With all the whites inside / The church, their less fortunate brothers / Emerged from everywhere to congregate / Beneath a tree. Huddled there, they passed / The Word of God around in whispers ... / When the whites inside lifted voices / In joyous song... / The blacks outside would hum along, / Adding their own touches... weaving melodic, / Harmonic, rhythmic patterns. / Thus the spiritual was born. / Highly emotional worshipping of God / In SONG" (217).

42. Ellington, "Black, Brown, and Beige" script.

43. While appreciating the vocalist for "Come Sunday," the jazz critic Nat Hentoff was dismissive of the song's message (likely a reflection of his nontheistic personal orientation). In his Black, Brown, and Beige review, for which he rated the album "a major jazz work," Hentoff wrote, "What makes this set most valuable are the simple, fervent vocals of Mahalia Jackson. She first burns the banality from the lyrics of Come Sunday and at the close of the record adds a moving interpretation of The Twenty-third Psalm." Despite the later popular acclaim for Mahalia Jackson's vocal rendition of "Come Sunday," a 1959 review of Ellington's Black, Brown, and Beige recording of the same year was generally dismissive of Jackson's involvement in the project, characterizing her singing as "inappropriate" and often unintelligible while deeming the text "troubling in that [the words] exemplify the preposterous gulf that always seems to divide jazz music from its 'lyrics.'" See Nat Hentoff, "Black, Brown and Beige Review," Hi Fi \& Music Review (November 1958): 98-99; Robert D. Crowley, "Black, Brown, and Beige after 16 Years," in Tucker, The Duke Ellington Reader, 181.

44. Author's transcription. From Duke Ellington, Black, Brown and Beige-featuring Mahalia Jackson, Columbia, EJC55430, 1958 [1999], compact disc.

45. See Matthew 6:25-34; Luke 12:22-34.

46. Paul Allen Anderson, Deep River: Music and Memory in Harlem Renaissance Thought (Durham, N.C.: Duke University Press, 2001), 225.

47. James Weldon Johnson, God's Trombones: Seven Negro Sermons in Verse (New York: Viking Press, 1927 [1955]), 5.

48. Ibid., 6-7. 
49. Marcellus Blount, "The Preacherly Text: African American Poetry and Vernacular Performance," PMLA 107, Special Topic: Performance (May 1992): 586.

50. Johnson, God's Trombones, 8-9.

51. "Is That Religion?" was recorded earlier in 1930 by Cab Calloway and his Orchestra, featuring "call-and-response" vocals from a chorus. According to a Chicago Defender article in April 1931, the Calloway version of "Is That Religion?" was "adjudged one of the best discs of the month." Pittsburgh Courier reader Annette Brown wrote to the paper that "Is That Religion?", as performed by Belton's Florida Syncopators, was one of her favorite tunes. See "Going Backstage with the Scribe," Chicago Defender, April 4, 1931, 5; Floyd G. Snelson, Jr., "Duke Continues to Lead in Big Courier Contest; Others Gain," Pittsburgh Courier, September 26, 1931, 11.

52. Teresa L. Reed, The Holy Profane: Religion in Black Popular Music (Lexington: University Press of Kentucky, 2003), 77-78.

53. Author's transcription. From Duke Ellington, Early Ellington: The Original Decca Recordings, Verve, B000003N42, 1994, compact disc.

54. My People was first featured in the Century of Negro Progress exhibition in Chicago in the summer of 1963. Although attendance reached about one hundred thousand, this number was well short of the anticipated eight hundred thousand attendees that summer. Reviews of My People appeared in Variety magazine, the Chicago Defender, and Jazz magazine. See Cohen, Duke Ellington's America, 392-98. Coverage of the exhibition appeared in major black press outlets as well as a January 18, 1964, New York Amsterdam News review and a February 13, 1964, Los Angeles Sentinel review of the album. Jesse H. Walker, "Theatricals" columnist for the Amsterdam News, wrote that the album is "at its best... when it's featuring straight jazz" but that "it becomes a bit pretentious when it dovetails into social comment-with the possible exception of Duke's 'King Fit The Battle of Alabam.'" In the Sentinel, Stanley G. Robertson wrote that My People "will rank on a par with Duke's milestone, 'Black, Brown and Beige'. It will be as absorbing as his 1957 television special, 'A Drum Is A Woman'. And the oldtimers who were privileged to see it, will place this epic on the same level as his 1941 musical, 'Jump For Joy.'”

55. Cohen, Duke Ellington's America, 393.

56. Author's transcription. From Duke Ellington, My People, Legacy, AK-52759, 1963 [1992], compact disc. On phonograph preachers, 
see Lerone A. Martin, Preaching on Wax: The Phonograph and the Shaping of Modern African American Religion (New York: New York University Press, 2014).

57. Blount, "The Preacherly Text," 583-84.

58. This speech echoed the content of earlier public statements Ellington made about African American history, including a February 9, 1941, address titled "We, Too, Sing 'America"' (influenced by Ellington's friendship with Langston Hughes), which he delivered at the Scott Methodist Church's Annual Lincoln Day Services in Los Angeles. The California Eagle, a prominent African American newspaper, published the majority of the speech on February 13, 1941. If this 1941 audience interacted with Ellington in call-and-response fashion, then it is reasonable to suspect that he attempted to recreate and represent a scene common to most African American congregations. See Tucker, The Duke Ellington Reader, 146-84.

59. Author's transcription. From Ellington, My People. Harvey Cohen describes this monologue as Ellington adopting "the persona of a 'soap box speaker' as he listed black values and achievements in an impassioned preacher's cadence." Cohen, Duke Ellington's America, 393. My contention is that, while secular, public speeches in African American communities may have elicited similar "call-and-response" participation by gathered crowds, "secular" black oratory has its origins in religious black preaching. Similarly, political messages were likely to emanate from church pulpits, so there is little need to overlook the deeper religious content and story in this public rhetorical style.

60. In 2007, R\&B artist Angie Stone included excerpts from Ellington's speech in a track also named "My People" on her 2007 album The Art of Love and War. James Ingraham sings a verse in the song, which states, "People, my people, keep striving / There's a greater master plan / We need to know our history / We were kings and queens of the greatest dynasty."

61. Jerry Watts, ed., Harold Cruse's The Crisis of the Negro Intellectual Reconsidered (New York: Routledge, 2004), 110.

62. Weisenfeld, Hollywood Be Thy Name, 4.

A B S TRACT Edward Kennedy "Duke" Ellington (1899-1974) emerged within the jazz profession as a prominent exponent of Harlem Renaissance racial uplift ideals about incorporating African American culture into artistic production. Formed in the early twentieth century's middle-class 
black Protestant culture but not a churchgoer in adulthood, Ellington conveyed a nostalgic appreciation of African American Christianity whenever he wrote music to chronicle African American history. This prominent jazz musician's religious nostalgia resulted in compositions that conveyed to a broader American audience a portrait of African American religiosity that was constantly "classical" and static-not quite primitive, but never appreciated as a modern aspect of black culture.

This article examines several Ellington compositions from the late 1920s through the 1960s that exemplify his deployment of popular representations of African American religious belief and practice. Through the short film Black and Tan in the 1920s, the satirical popular song "Is That Religion?" in the 1930s, the long-form symphonic movement Black, Brown and Beige in the 1940s, the lyricism of "Come Sunday" in the 1950s, and the dramatic prose of "My People" in the 1960s, Ellington attempted to capture a portrait of black religious practice without recognition of contemporaneous developments in black Protestant Christianity in the twentieth century's middle decades. Although existing Ellington scholarship has covered his "Sacred Concerts" in the 1960s and 1970s, this article engages themes and representations in Ellington's work prefiguring the religious jazz that became popular with white liberal Protestants in America and Europe. This discussion of religious narratives in Ellington's compositions affords an opportunity to reflect upon the (un)intended consequences of progressive, sympathetic cultural production, particularly on the part of prominent African American historical figures in their time. Moreover, this article attempts to locate the jazz profession as a critical site for the examination of racial and religious representation in African American religious history.

Keywords: jazz, African American religion, Come Sunday, race, Harlem Renaissance 